\title{
Article \\ "Battlers" and Their Homes: About Self-Production of Residences Made by the Brazilian New Middle Class
}

\author{
Priscilla Nogueira \\ Institute for European Urban Studies, Bauhaus University Weimar, Belvedere Alee 5, 99425 Weimar, Germany; \\ E-Mail: priscilla.nogueira.haque@uni-weimar.de; Tel: +49-160-96298982
}

Submitted: 15 May 2014 | In Revised Form: 24 July 2014 | Accepted: 1 August 2014 | Published: 9 April 2015

\begin{abstract}
The article presents preliminary results and qualitative analysis obtained from the doctoral research provisory entitled "How do Brazilian 'battlers' reside?", which is in progress at the Institute for European Urban Studies, Bauhaus University Weimar. It critically discusses the contradictions of the production of residences in Brazil made by an emerging social group, lately called the Brazilian new middle class. For the last ten years, a number of government policies have provoked a general improvement of the purchasing power of the poor. Between those who completely depend on the government to survive and the upper middle class, there is a wide (about 100 million people) and economically stable lower middle group, which has found its own ways of dealing with its demand for housing. The conventional models of planning, building and buying are not suitable for their technical, financial and personal needs. Therefore, they are concurrently planners, constructors and residents, building and renovating their own properties themselves, but still with very limited education and technical knowledge and restricted access to good building materials and constructive elements, formal technicians, architects or engineers. On the one hand, the result is an informal and more or less autonomous self-production, with all sorts of technical problems and very interesting and creative spatial solutions to everyday domestic situations. On the other hand, the repercussions for urban space are questionable: although basic infrastructure conditions have improved, building densities are high and green areas are few. Lower middle class neighbourhoods present a restricted collective everyday life. They look like storage spaces for manpower; people who live to work in order to be able to consume-and build-what they could not before. One question is, to what extent the latest economic rise of Brazil has really resulted in social development for lower middle income families in the private sphere regarding their residences, and in the collective sphere, regarding the neighbourhoods they inhabit and the urban space in general.
\end{abstract}

\section{Keywords}

Brazil; collective; residences; families; neighbourhoods; new middle class; private; self-production; space; urban

\section{Issue}

This article is part of the special issue "Housing and Space: Toward Socio-Spatial Inclusion", edited by Dr. Dallas Rogers (University of Western Sydney, Australia), Dr. Rae Dufty-Jones (University of Western Sydney, Australia) and Dr. Wendy Steele (RMIT University, Australia).

(C) 2015 by the author; licensee Cogitatio (Lisbon, Portugal). This article is licensed under a Creative Commons Attribution 4.0 International License (CC BY).

\section{Introduction}

Considering architecture as "all spaces modified by human work" (Kapp, 2005), ordinary architecture can be considered the architecture of the commons, not that of institutional buildings and big projects. In this case, the best term to define it is "popular", whose Latin origin is "the group of citizens which exclude, on the one hand, the most privileged patricians whom was reserved the Senate and on the other, the less fortunate, the plebs, the dispossessed, (...) typical from the intermediate layers of the population" (Weimer, 2005)-buildings with no distinctive value for the architecture field.

Services traditionally provided by architects and 
formal models of planning and building are not suitable for the everyday needs of most popular clients, who are still typical self-producers in Brazil (Nogueira \& Kapp, 2010), being concurrently planners, constructors and residents, building and renovating by themselves. Although preserving some level of autonomy, they normally present limited education and technical knowledge and restricted access to resources and formal technicians. On the one hand, architects are recognised as distant and unhelpful luxury professionals occupied with big projects, providing products only understandable for specialists. On the other, despite problems with building techniques, materials and manpower, self-production practices have reached a very high demand, not concerned by the architectural field and not supplied by any government sector and social housing institution in Brazil.

For the last ten years, a number of socioeconomic policies have provoked a general improvement of the purchasing power of the poor, part of a government strategy of economic growth. Between those who completely depend on the government to survive and the upper middle class, there is a wide (about 100 million people) and economically stable young middle group that “(...) works 10 to 14 hours a day, has two or more jobs, studies at night, works during the day and lives to work and to consume what they could not buy before. (...) these people come from structured families with a strong work ethic and perseverance. Unlike the real middle class, they have little embodied cultural capital, making their lifestyle and consumption patterns essentially different from the established middle class." (Souza, 2010a, translated by the author)

This population has always found own ways of dealing with their demand for housing, since government policies are not able to attend to them. Nowadays they can afford goods and services that were not possible before, including regular and irregular pieces of land, apartments, houses and building materials. On the one hand, we can see informal and more or less autonomous self-production with all sorts of technical problems and interesting and creative spatial solutions for everyday domestic situations. On the other, although basic urban infrastructure conditions like paving, public sanitation and illumination have improved in favelas and distant neighbourhoods, the urban environment's quality is questionable. The private sphere became better, but still public places are spatially poor, with high constructive densities, few green areas and restricted collective everyday life. Lower middle class neighbourhoods look like storage spaces for manpower; people who live to work in order to be able to consume-and build-"what they could not buy before" (Souza, 2010b).

Although this phenomenon suggests the existence of a high demand for housing, instead of looking for so- lutions, this paper focuses on analysing how this social group produce and reside, analysing five main issues, regarding social practices: (a) spontaneity of planning and building processes; (b) transformation and the use of the residence as an extra income source; (c) technical challenges of building, (d) creative use of the space and e) ordinary public spaces. Those aspects are discussed over a background of an emerging country claiming social development under a socioeconomic context safer than fifteen years ago. Besides this, this work considers to what extent the latest economic rise of Brazil, from 2003 to 2011 and the generation of this new social class has really resulted in social development in the private sphere, regarding residences, and in the collective sphere, regarding the neighbourhoods which people inhabit.

The field work for the $\mathrm{PhD}$ research which gives rise to this article lasted three months, from August to November 2013, and took place in Belo Horizonte and its metropolitan area, a 5 million person urban agglomeration, distributed in $9.467 .797 \mathrm{~km}^{2}$ in the southeast of Brazil (see Figures 1 and 2). The term "battler", used in the provisory title of the PhD dissertation, is a reference to the work of Professor Jessé Souza, a Brazilian sociologist who provides a sharp analysis of the origins and social practices that produce and reinforce social inequality. According to him, the new social group should not be understood as a middle class, but as a "new precarious working class" (Souza, 2010b), with reduced educational and social capital (Bourdieu, 2007).

The social distinction represented by the possession and lack of economic and non-economic capital strongly manifests itself and influences Brazilian everyday life in education and health care systems, the structure of families, religious practices, the electoral process, the cultural industry and also the production of space, from residences to whole cities. Although the approaches of the French sociologist Pierre Bourdieu and Professor Jessé Souza are the most important theoretical basis for the present investigation, some statistical parameters are useful to locate the new social group in the Brazilian social pyramid. According to FGV (Fundação Getúlio Vargas), one of the most relevant statistical research institutes in the country, the Brazilian new middle class comprised more 39.6 million Brazilians, who had risen from classes " $D$ " (monthly income between about U\$330 and U\$530) and "E" (the poorest, with monthly income up to about U\$330)to class " $C$ " between 2003 to 2011. Class " $C$ " families present incomes between about U\$530 and U\$2.280 per month. In 2011 more than a half of all Brazilians belonged to this lower middle group (50,05\%), about 100.5 million people. Optimistic economic research institutions estimate that they will make up about $60 \%$ in 2014 , as can be observed in Figure 3 (Neri, 2011). 


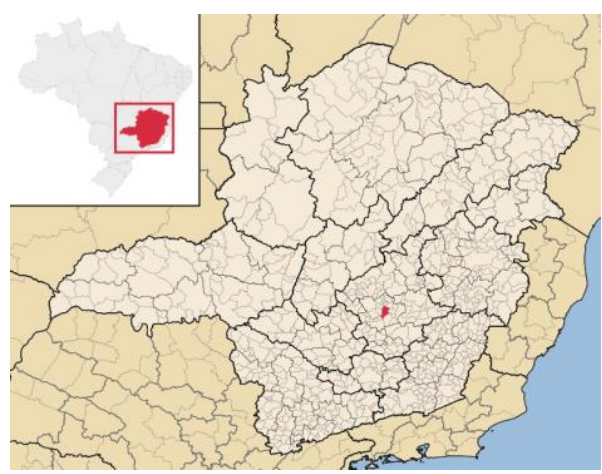

Figure 1. Belo Horizonte, Minas Gerais, Brazil. Source: www.wikipedia.org/minasgerais

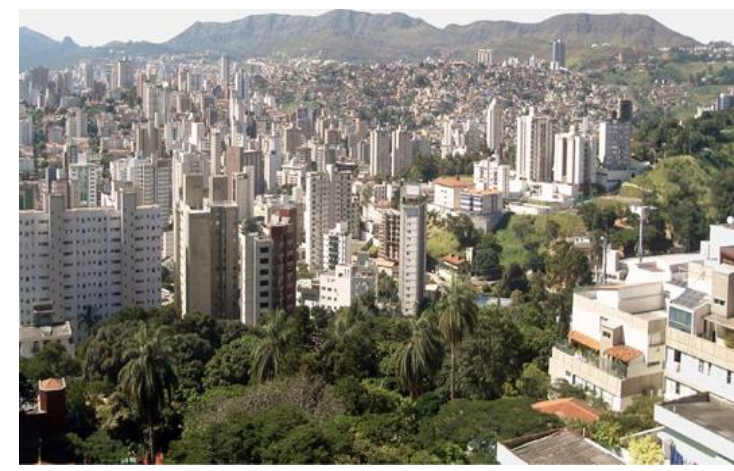

Figure 2. Overview of Belo Horizonte.

Source: www.wikipedia.org/belohorizonte

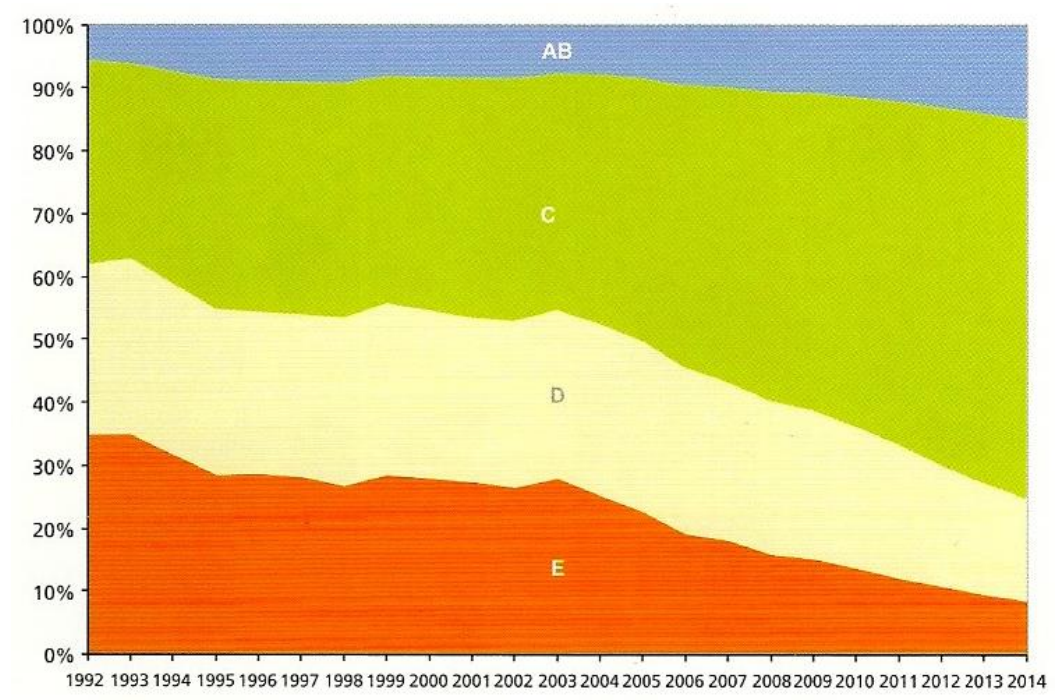

Figure 3. Social classes' distribution 1992-2014. Source: PCS/PGV, based on microdata from PME/IBGE. (Neri, 2011, p. 294)

\section{Research Methods}

The methods used for field research were based on oral history (Leavy, 2011). They combined unstructured interviews with participative observation in "battler" families' residences (Descombe, 2003). The main idea of this research strategy was to achieve an honest and spontaneous dialogue (between the researcher and the research object), instead of "question-answer" interviews or isolated observations of the researcher without input from residents and neighbours. The aim was to get as much information as possible, both oral and visual, without forcing quick feedback or pressuring people to speak. Therefore, the first precondition for the meeting between researcher and informants was preferably to contact a trustworthy local person, who could introduce one to the other. The second precondition was to rule out direct questions, instead using a guide of investigation topics. In this case, topics were defined by a dialectical exercise, the objective of which was to obtain different perspectives of the central re- search issue, looking at it from different points of view. The main issue was divided into a first set of investigation items, which were again subdivided. From these, more specific subjects were systematically identified and once more subdivided, as represented in Figure 4. It is expected that this exercise allows the researcher to identify existent controversial and complex relations, which enrich the investigation (Konder, 1981).

Local people were found and contacted through previous and ongoing research carried out by the MOM (Morar de Outras Maneiras, UFMG, Brazil) group. The research group has worked with self-producer and selfbuilder families in favelas and peripheral neighbourhoods since 2005 and has a large list of local contacts, which are open to helping with future research. Some residents that had already taken part of some of the group's activities perfectly fitted the profile of a "battler". They were invited to contribute to the new research and recommended neighbours, relatives or friends with equivalent profiles. 


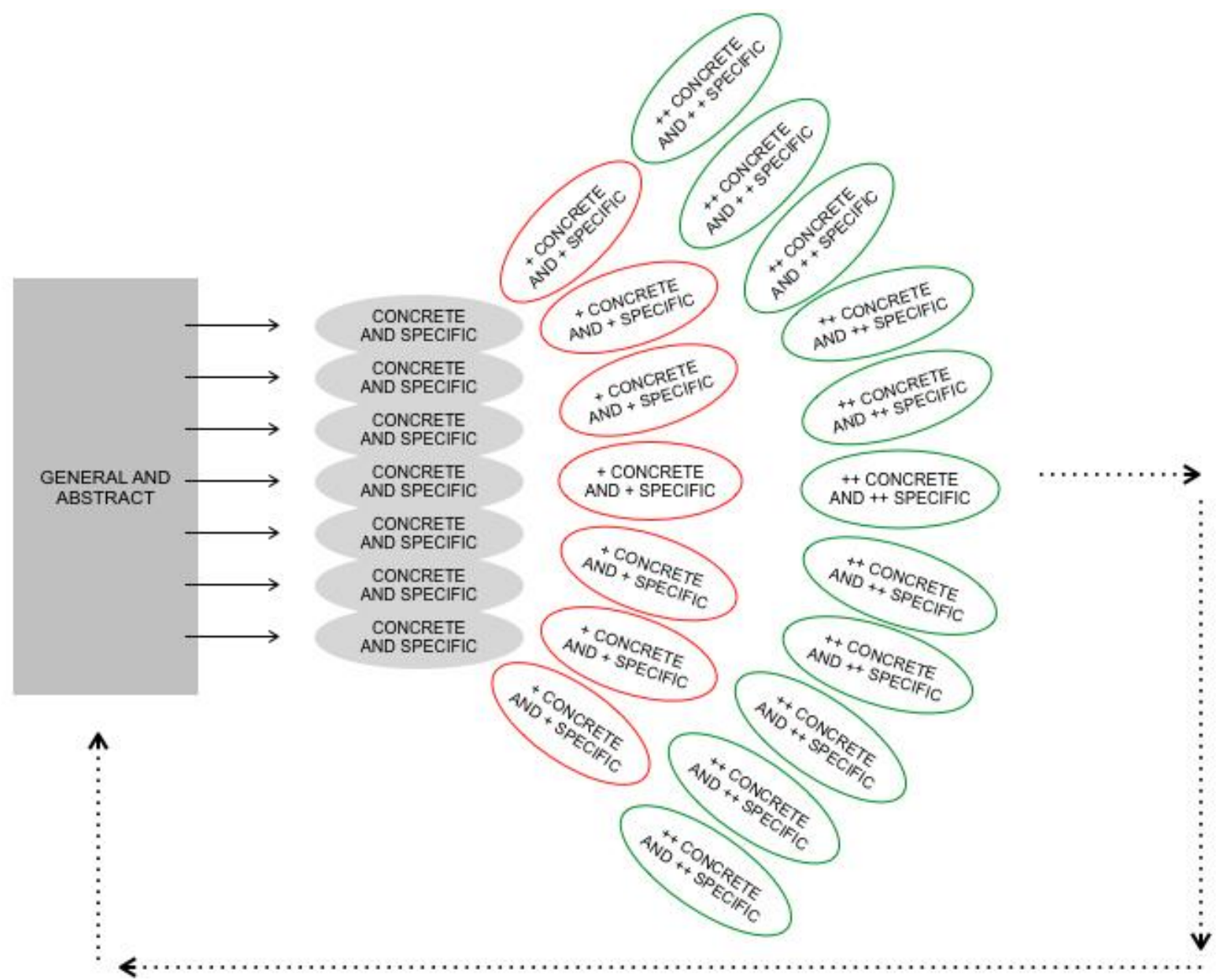

Figure 4. Scheme of dialectical thought. Source: elaborated by the author, inspired by Konder (1981).

So, the availability of informants determined which parts of the city the researcher would go through. Neighbourhoods were not chosen, rather, their inhabitants-those whose socioeconomic conditions and social practices would fit the profile of a self-producer "battler" family-were chosen.

Other investigations in favelas have confirmed a high level of spontaneity of locals, which helped the researcher to access information (Grupo de Pesquisa Morar de Outras Maneiras/Universidade Federal de Minas Gerais [MOM/UFMG], 2012). Therefore research topics did not need to follow a sequence during the conversation and interventions of the researcher were maximally avoided. Generally, residents were not shy and after the proposition of an initial conversation topic by the researcher, they easily started telling stories, such as how they arrived in the neighbourhood or about renovations they were currently doing. The conversations were audio-recorded on the speakers and avoid the written reproduction of the speech. An interview is a process, formed by different actions. The moment the researcher listens is not the moment he takes photos or makes notes. Such differentiation is very important to obtain successful feedback. In this case, at first the researcher listened to the informant in a quiet and comfortable place of the residence and recorded all the conversation. Only after that, the researcher walked through the house, took pictures and recorded videos. During this excursion in the residence and its surroundings, the conversation spontaneously continued and was still recorded. Each visit took approximately one and a half hours. Soon after the visit, the researcher made drawings and sketches in order to keep important details in mind or to highlight remarkable aspects.

Residences and families were organised in clusters, groups of houses in the same neighbourhood. Clusters allowed the investigation of interferences and consequences of self-production in a local scale-a bigger scale than the house and a smaller scale than the city. This organisation was possible because of the local people who were previously known and because of their recommendations. This strategy, called the "snow-ball effect" (Descombe, 2003), legitimates the work and makes it easier to get more participants, in this case preferably those who were building or renovating their homes at the time.

During the field work, 33 self-producer families were visited. This paper discusses social practices of eight families, inhabitants of two clusters in two different neighbourhoods-Aglomerado da Serra and São Joaquim, in Belo Horizonte and in Contagem, a satellite city nearby, respectively. Families will be not presented one by one, but through remarkable social practices that describe how Brazilian "battlers" reside. In both clusters, inform- 
ants knew each other and preserved a close relationship. Some of them were relatives, while others had a working relationship or were simply good friends. Their identities will be preserved.

Figures 5 and 6 present each cluster and some of the relationships among residents. Each letter represents a case, defined by a building. As demonstrated, each building can have more than one function. Each building belongs to one family. Each family has one informant, who had received the researcher and informed the research.

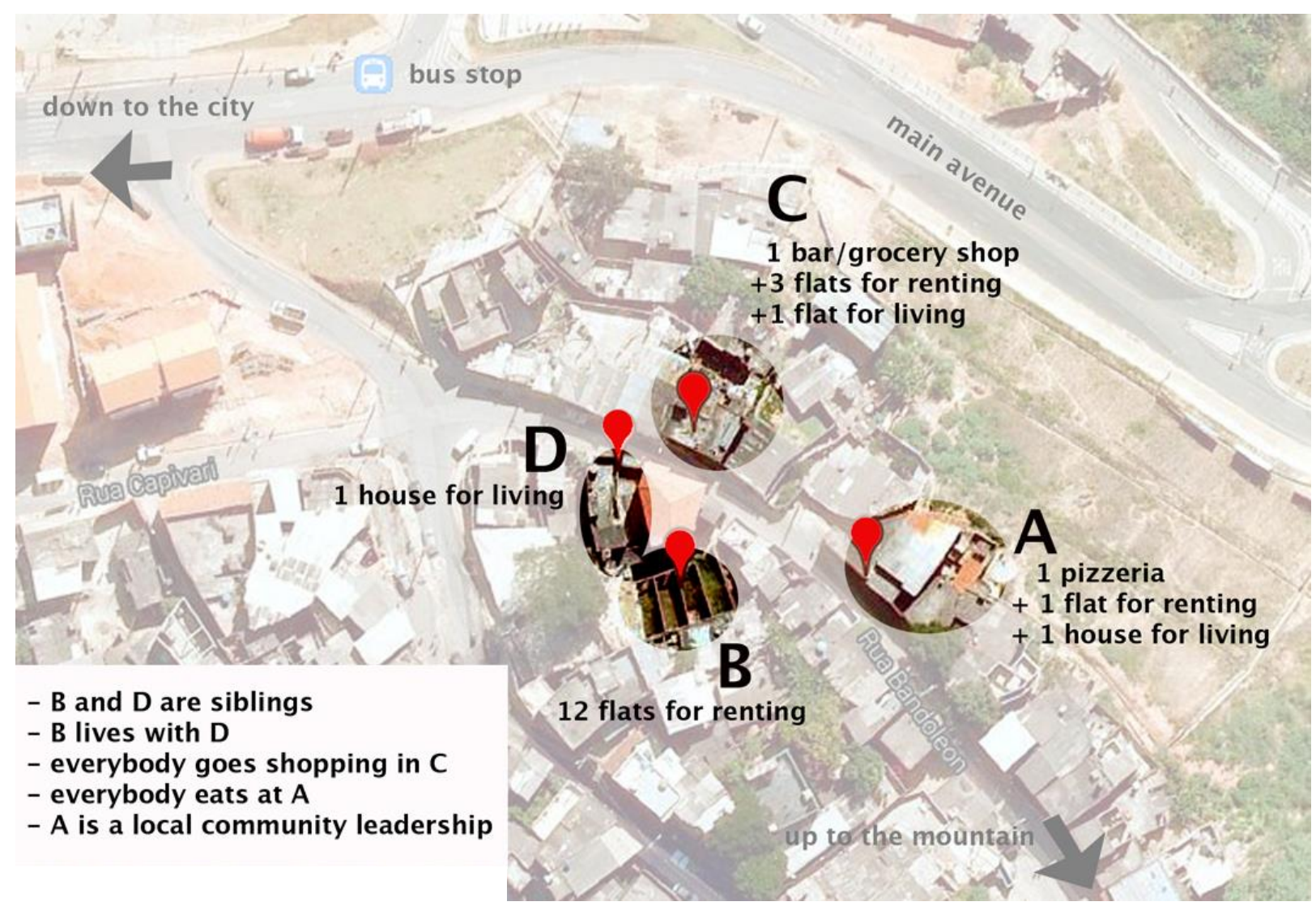

Figure 5. Cluster Aglomerado da Serra, Belo Horizonte. Buildings are unfinished, with some work or renovation still on course. Source: elaborated by the author, 2014.

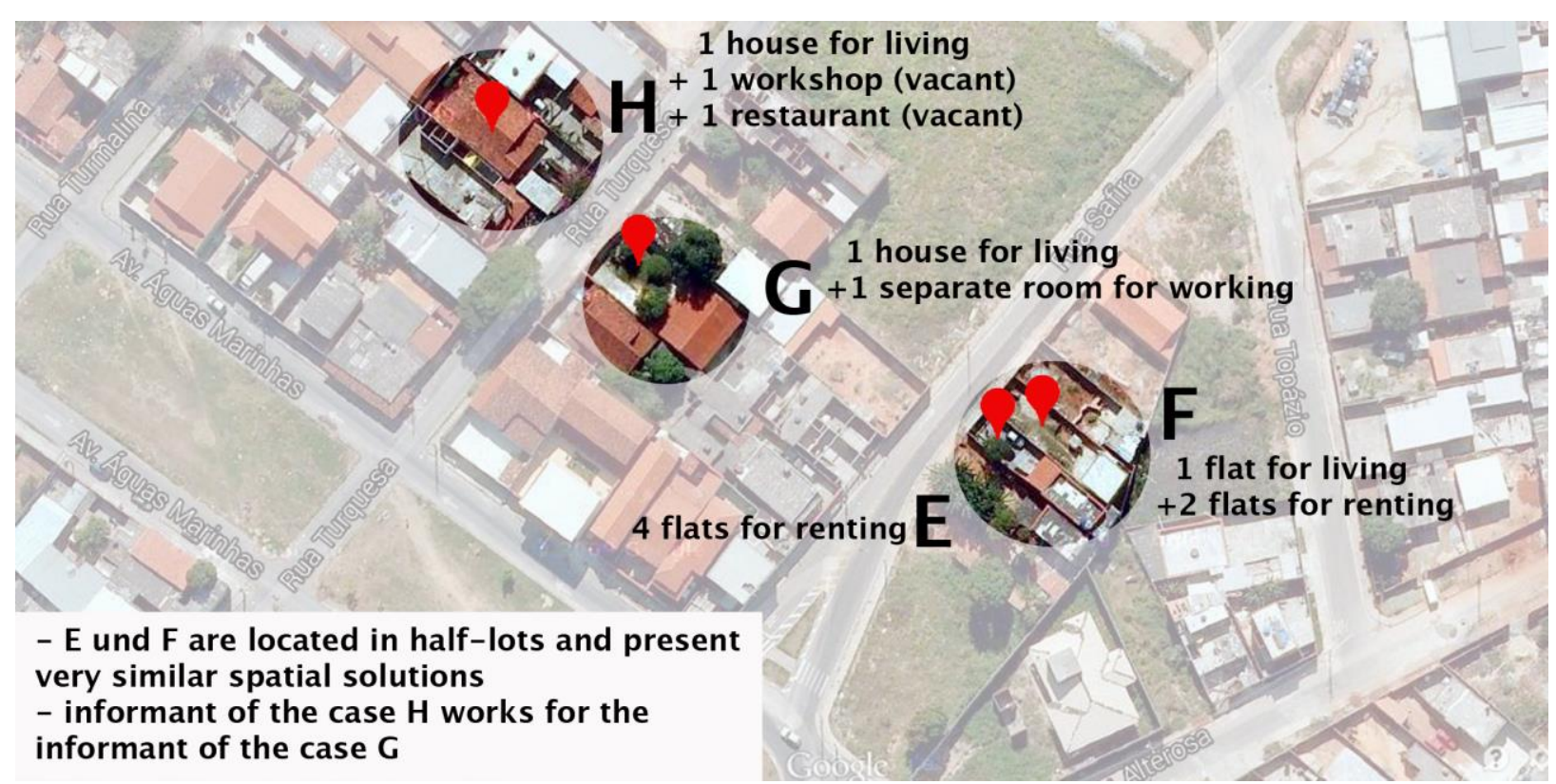

Figure 6. Cluster São Joaquim, Contagem. Buildings are unfinished, with some work or renovation still on course. Source: elaborated by the author, 2014. 


\section{How Do Brazilian "Battlers" Reside?}

\subsection{General Aspects of the Territory}

Normally "battlers" live in irregular lands in longestablished slums, relatively well connected to the city centre and with a tolerable infrastructure and in peripheral neighbourhoods in formal subdivisions provided with infrastructure, but still with a reduced level of urban services, schools, social and health care and entertainment options. In any situation, "battlers" selfproduce their residences, from building new additions and complete new houses to renovations of existing spaces. Although formal apartments are finished products offered on the real estate market, they are also objects of self-production processes, since inhabitants change internal spaces and building materials to attend to their needs.

One cluster is located in one of the eight vilas (small favela) of the Aglomerado da Serra, a long-established 43 thousand-person slum, very well connected to the city centre, with relative good infrastructure conditions and a very strong urban identity (Figure 7). For the last five years, the neighbourhood has been affected by consecutive infrastructure interventions as part of an audacious plan of economic growth and development created by the current federal government. One of the interventions was the construction of a fast transit avenue that crosses the neighbourhood in order to relieve the transportation conditions between neighbouring districts and the city centre. For that purpose, many residences were demolished and families had to be relocated. Some of them had lived there for more than 40 years and had to leave friends and neighbours and change their lifestyles, moving to a far away neighbourhood or to apartment buildings with questionable building quality, built and provided by the state.

The second group of residences is located in a peripheral formal neighbourhood of Contagem, an industrial city of 200 thousand people, located in the metropolitan area of Belo Horizonte (Figure 8). The district,

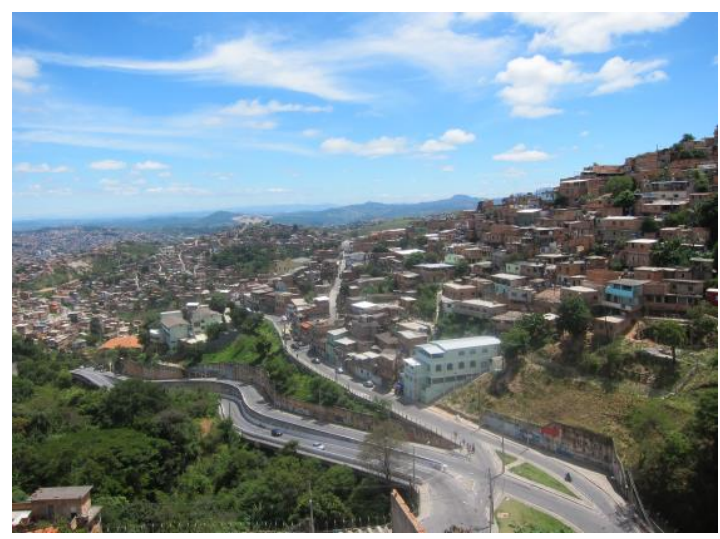

Figure 7. View of Aglomerado da Serra, from the rooftop of A. Source: author's archive, 2013. called São Joaquim, is $10 \mathrm{~km}$ away from the city centre of Contagem and about $15 \mathrm{~km}$ to the centre of Belo Horizonte. Although it is a typical lower middle class neighbourhood, most people have cars to move around, because of public transportation conditions. There is only one train line and the hilly topography of the region restricts the use of bicycles. About five and a half million inhabitants of the metropolitan area of Belo Horizonte depend on cars and buses for transportation. Streets and avenues cannot support such demand anymore. Traffic jams have become a routine occurrence and it is not by chance that the most common consumerist dream is a private car, strongly influenced by the automotive industry, whose production in Brazil has achieved record levels. The district of São Joaquim is relatively recent-much of the area received infrastructure conditions in the late 70's, when the land was for the first time subdivided and started to be sold. The area is intersected by high tension electrical lines which forbid the private and public use of some areas. There are continuous large empty spaces without any use, but parks and squares simply do not exist. Another problem faced by inhabitants of the neighbourhood is the elevation of the water level during the rainy season. A local river was covered during the formation of the subdivision to give place for new streets. Besides the lack of permeable areas, the water passage is not large enough for the volume of rain water. The results are constant floods, which bring about risks of contamination and multiple problems for the inhabitants.

Another aspect of differentiation among residence situations are building types. They are also quite heterogeneous in slums, where many present different geometries and demand different spatial settings. Although there are so many different shapes and volumes, the use of concrete structures, pre-assembled slabs and clay bricks is dominant. Buildings seem to be unfinished, because few external walls are painted. Front walls are mostly located on the border with sidewalks and streets. As Figure 7 shows, the landscape is an ocean of clay bricks. In peripheral subdivisions, con-

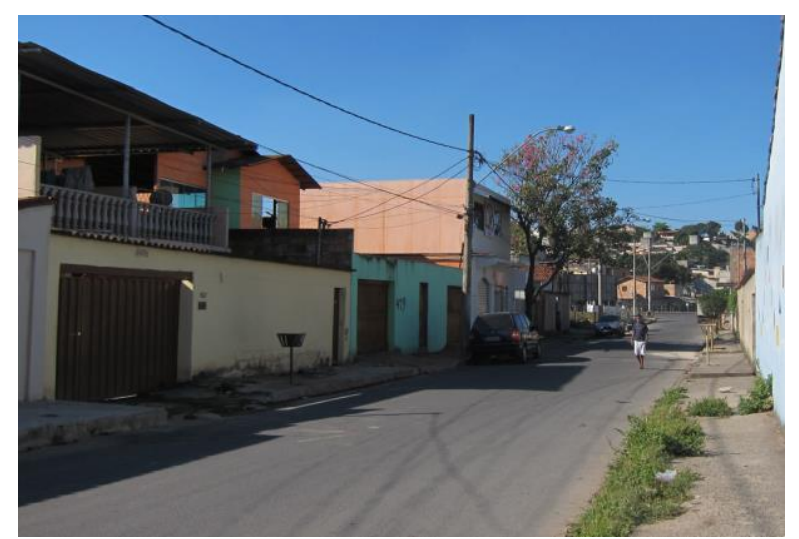

Figure 8. Street view of São Joaquim. The green house on the left is $\mathrm{H}$ and the yellow front wall on the right is G. Source: author's archive, 2013. 
crete structures and pre-assembled slabs also prevail and the use of the space in regular lots, which vary around $360 \mathrm{~m}^{2}$, obeys more or less the same geometric patterns because of urban regulations, the selection of building materials available in the market, and the construction techniques commonly used. Pedestrians can rarely see inside the lots, since most of them are protected by high front walls or grills. The unfinished appearance of constructions is the same as in slums, but finished buildings are also found, with very good conditions of construction.

\subsection{Socioeconomic Origins}

As Belo Horizonte is a young city, with only 116 years of foundation, older generations of inhabitants usually have origins elsewhere. Still today, many families leave their hometowns in the countryside and migrate to big cities looking for a better life. They run away from hunger, bad working conditions and poverty, pursuing the dream of the life in a metropolis, where theoretically there are jobs for everyone. This is a common aspect of families from Aglomerado da Serra. They originated in the north of Minas Gerais and southwest of Bahia, an economically poor region, climatically dry, whose main economic activity still comes from the cultivation of vegetables and some cattle breeding. Big agricultural entrepreneurs have incorporated small properties and the farmers and their families have had to submit themselves to low wages and even worse working conditions. Such an atmosphere collaborates to feed the illusion of a new life, much better than before, and a less exhaustive and clean work. Pursuing this dream, older generations came to Belo Horizonte with no money but hope, and installed themselves in the small huts of favelas, bought by family members and friends who had arrived before. The early everyday life in a favela was hard but pleasant. Many social practices today come from this time. The intensive collaboration among neighbours and families and the use of any small piece of land for some subsistence farming are still very prominent practices, while the family house grew at the same rate as the family. The father used to build an extra room himself, waiting for the next baby. After 50 years, old huts are today three-floor family houses, many of which still belong to the same families. Over the years many early inhabitants sold their properties to new ones. In all cases, the achievements came step by step and took decades. This is one of the reasons why, for example, traditional methods of building and planning do not suit this population. Even having grown economically, inhabitants are still used to understanding and dealing with a house as a process and not as a finished product. First, successive governments were never able to protect and maintain this population in their hometowns and second, big cities were not and still are not prepared to receive them.
There was and still is a high demand for housing for poor migrants, with few chances to reach formal solutions. At that time and still today, the only possibility is to settle in an informal land. Besides, until the 60's there was no electricity, no piped water or sewage pipe and individuals had to do everything by themselves, bringing water on the top of their heads straight from the springs.

São Joaquim has been provided with basic infrastructure conditions since the beginning, but still the public water distribution system has never been properly dimensioned for the rainy season. Floods are still frequent and cause all sorts of material losses for the inhabitants. The history of the residents is more recent. The families investigated in this study used to live in different parts of the metropolitan area or in the surroundings of the neighbourhood and arrived there in the late 70's, at the beginning of the land's occupation. At that time, the neighbourhood was part of a land provision for low income inhabitants from Contagem. The lots are relatively big, $14 \mathrm{~m} \times 30 \mathrm{~m}$, but at that time cheap, since they are located far away from the city centre and with almost no services nearby. Residents say they were "in the middle of nothing". Most lots were bought with letters of credit and paid over decades, while houses were self-built or selfproduced with families' own savings during long periods of time.

Since the first inhabitants of Aglomerado da Serra had almost no education or any other working experience unless farming, they had to take the worst jobs. Most men started working as bricklayers' helpers and women as housemaids, baby sitters or cleaners. Higher education levels have become one of the main objectives for the younger generations of these families nowadays. The pursuit of a degree is a symbol of social status, but also a platform to achieve better working conditions. The life of a typical farming family in the big city is a life exclusively dedicated to work. There is no free time, vacations or holidays. The income from regular jobs is complemented by small services done during weekends and after work. Such efforts have very clear targets - the priorities are education for the children, and the house. Those two topics are extremely significant to the self-esteem of a family under such conditions.

The socioeconomic conditions of the residents of São Joaquim were different. In São Joaquim most of them were not poor. They were employees with low but regular salaries, which allowed them to afford monthly payments for a lot and to initiate the construction of a small house. One of the oldest residents of the cluster in São Joaquim reports that a standard project was given to new residents with the purchase of the lot. Her husband built the house exactly like the drawings. Internal partitions still remain, as in the original sketch, and it was only renovated last year. This lady had had a very difficult time during the 90 's, when 
her husband got sick for more than a decade and could not work anymore, needing her complete care, which meant they could never invest in the household. Besides this isolated case, most residences in the neighbourhood have been renovated and received new spaces, but in many of them it is still possible to recognise the original model.

All interviewed families, from both clusters, began life in the area sleeping together in only one room, using an outside bathroom with a poor metallic roof, and cooking with small stoves made of stacked bricks. Month after month, having spent the most part of their salary on subsistence items, some food, basic clothes and transportation to go to work, the rest of their earnings were all invested in the household. The roof was changed, tiles installed, the bathroom renovated. One common and very remarkable aspect is how some building materials, like burnt cement on the floor and an asbestos roof, are still today stigmatised as symbols of poverty. People look forward to a solid, clean and safe house, built with "strong" and "long-lasting" materials-concrete slabs and tiles on the floor.

Nowadays, families are quite heterogeneous regarding their structures. One of the families presents a traditional family structure, with father, mother and children. Another is a family of women, where the traditional masculine figure does not exist. Although heterogeneous regarding their structures, both clusters present families with similar socioeconomic conditions. A strong work ethic is very present, often encouraged by neo-Pentecostalism practices, which have guided a certain life path and maintained family unity. There is also a noticeable collaborative atmosphere among family members; everyone contributes somehow to the household from a very young age, undertaking domestic tasks or working late into the night, with almost no vacations or holidays. A very high consumerist impulse can also be noticed, mainly focussed on buying goods that were previously not economically accessible, as well as the pursuit of a better and higher education, at least for the younger generations.

\subsection{Social Practices in Self-Production}

\subsubsection{Residences as Non-Stop Processes}

Step-by-step construction is common. At first only one room is completely built, with a separate toilet and an improvised kitchen outside. All family members use this single room for watching TV, dressing, studying and sleeping. Hereafter, different improvements are made step by step, like new additions and toilets inside the house. Case $A$ is a typical example of such a building process, as we can see in Figure 9. The house started to be built in 1974 and is still being renovated. It started with a single-room hut in the middle of the lot, with a toilet outside, a metallic roof and no internal fin- ishing-no tiles and no painting. After that a new toilet was built and two small patches of land were added to the original lot. Some time after, the whole house was demolished and a new one started to be built, exactly like the first-with one initial hub and consecutive additions along the years. The second house was a "real house", says the informant proudly when describing the "new" house, this time covered with concrete slabs. At that stage, in the 80 's, siblings were already working and could invest in the construction, while the mother's wage was used to provide subsistence. The second house underwent more than six renovations and today presents five bedrooms, three living-rooms, a big kitchen and two bathrooms, as well as a backyard, terrace and garage, where six family members live together. They still have new plans for the house and never thought about leaving the neighbourhood.

\subsubsection{Residences as Business}

A very common practice in low-income districts is the partition of one formal lot in smaller, independent parts. This phenomenon was observed two times in São Joaquim. As lots are relatively large, people often divide them to build housing units for selling or renting. Another strategy is to build on the top of existing houses with independent entrances, also with the purpose of renting or selling. As represented in Figure 10, building E originated from a half-lot and now four housing units for renting have been built. The neighbour, owner of building F, did almost the same. Today he has three housing units, from which two are rented out.

In Aglomerado da Serra some of the first inhabitants sold their plots of land and bought new properties in the same area. Older generations normally do not want to leave the neighbourhood, a feeling that is still present among younger inhabitants. Many of them prefer to invest in renovating the same residence, like the building $\mathrm{A}$, rather than moving to somewhere else. There are also some who want to leave the neighbourhood, but see it as a good place to invest, like the owner of the building $B$.

Real estate market negotiations are stronger than ever in the informal city, just as in the formal one. Building $B$ (Figure 11) belongs to a young entrepreneur of 33 years old. He started working at 13 , when he came from the North of Minas Gerais to live with his sister in Aglomerado da Serra. He seems to have a special talent for business and after working for years as a furniture assembler and seller in a number of different shops and local industries, he decided to start his own business, a furniture shop selling new and second-hand items, in the same neighbourhood. After some time in the business, he bought a tidy piece of land of $150 \mathrm{~m}^{2}$, 20 meters away from his sister's house, where he still lives. There, he is currently building a three floor apartment building with 12 housing units. He purpose- 
fully decided to go for this kind of enterprise. In his shop, he had the opportunity to get to know his potential tenants, their needs and limitations. In parallel, he learnt that buying land and building to rent out or to sell can be a very profitable investment, surely inspired by big entrepreneurs of the formal city. So, he soon bought some very cheap land from somebody who urgently needed to sell, and started to produce small flats. In the beginning he took a small loan to buy building materials and quickly started to build with no project, architects, licenses, insurance or any kind of for- mality, only the help of construction workers from the neighbourhood. At first he built only the ground floor. The units were only finished inside, but were quickly rented out. With the extra income, he invested in construction materials to start the second floor. The third floor is about to be finished and there is already a waiting list of potential tenants. Although eight units are already occupied, the building still seems to be under construction. Communal areas have no tiles on the floor, there are no protective railings along the stairs and external walls are stuccoed but not painted.

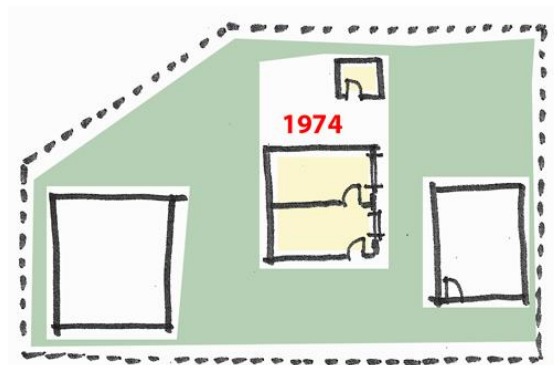

Ground Floor

1974

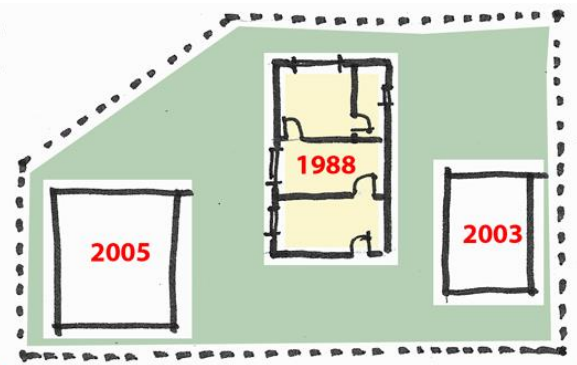

(1)

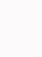

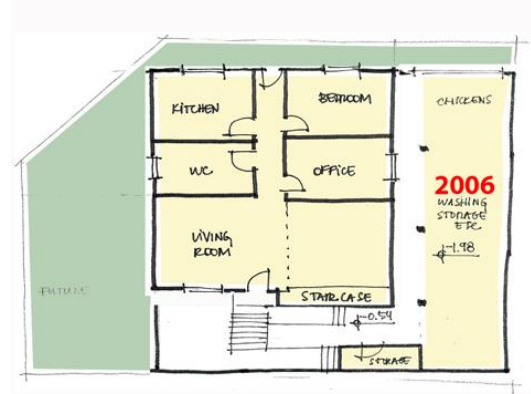

Ground Floor 2006

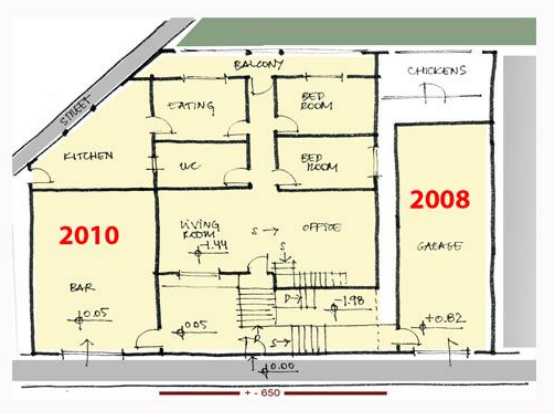

Ground Floor 2008
Upper floor 2009

\section{Upper floor 2011}

\section{Ground Floor} 2004 

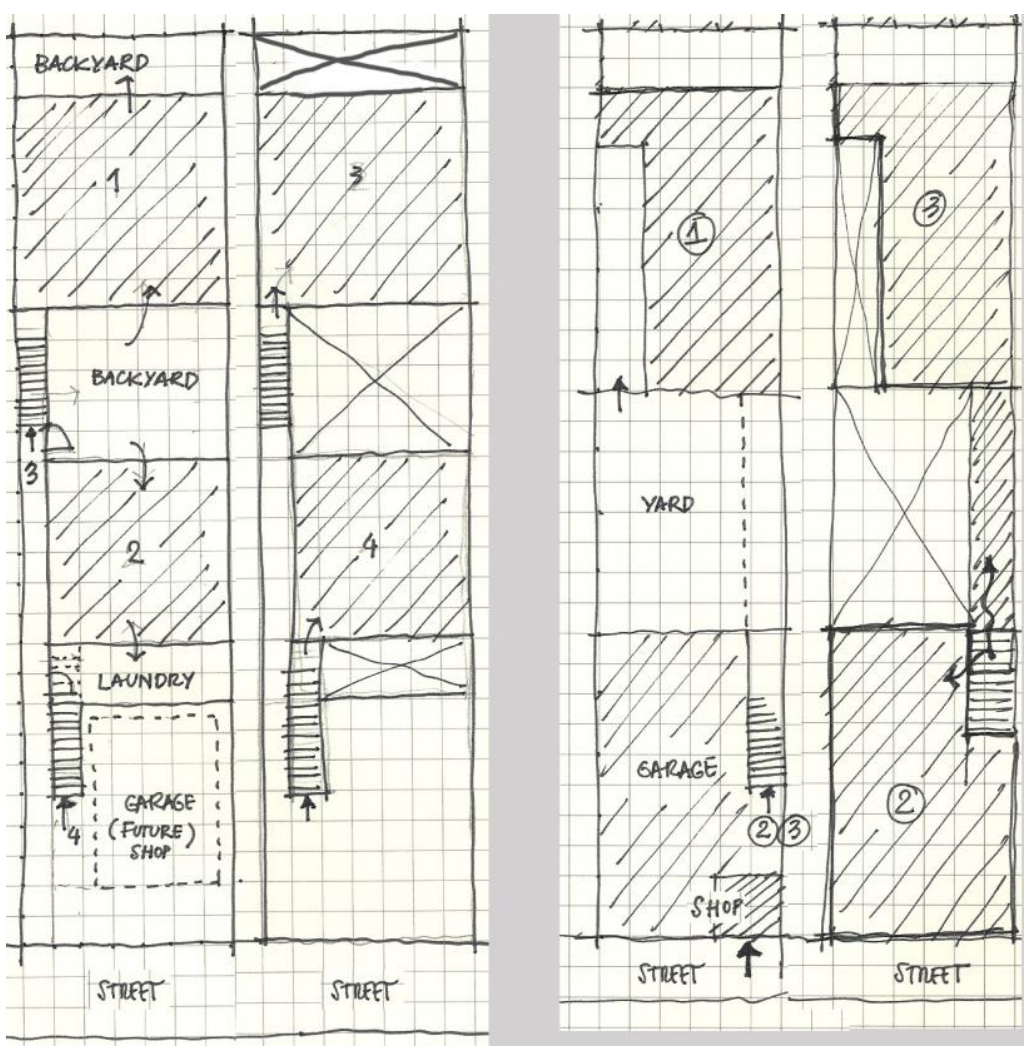

Figure 10. Cases $E$ and F, scheme of distribution of housing units. Numbers represent apartments and arrows represent accesses. Source: by the author, 2014.

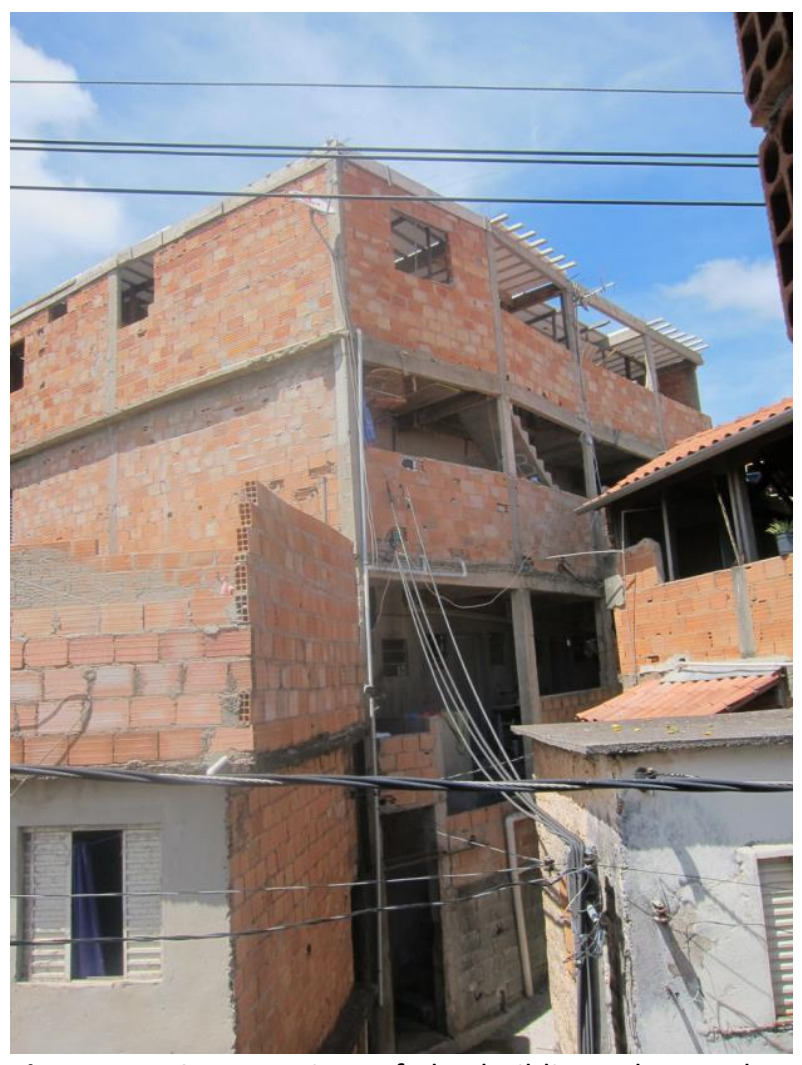

Figure 11. Case B, view of the building. Photo taken from the roof-top of the building of the case C. Source: author's archive, 2013.
Building $\mathrm{C}$ is another example of a business. In this case, the original house gave host to a grocery shop (Figure 12) on the ground floor, open to the street. It also functions as a bar, offering drinks and homemade food for workers, that quick stop there on their way home. The family lives in one of the two housing units in one of the lower floors. In the upper floor, the family is currently building an apartment, which they expect to rent out. The desire of the main informant, who works every day including weekends from seven in the morning to ten o'clock at night, is to assure her retirement with the rented flats.

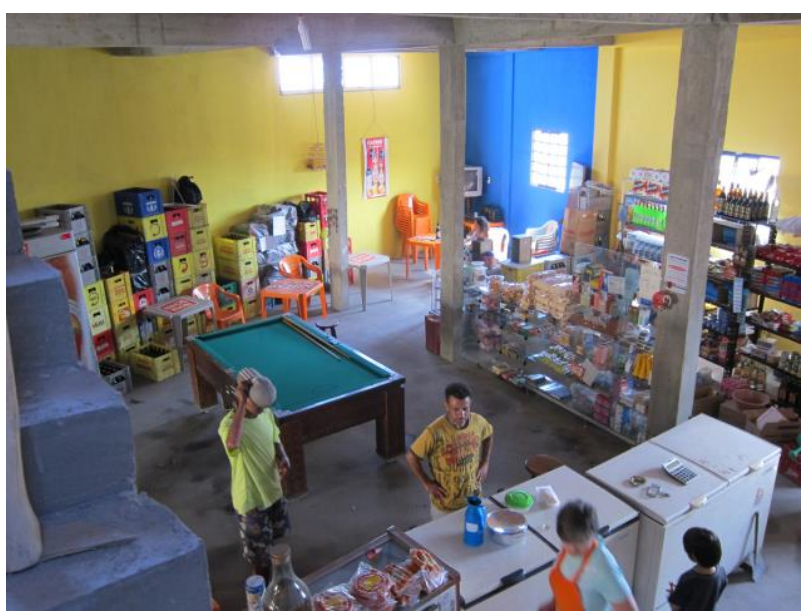

Figure 12. Case $C$, bar and grocery shop. Source: author's archive, 2013. 


\subsubsection{Residences as Technical Challenges, Exposing Social Problems}

In both clusters, residents are confronted by complicated infrastructure problems. Aglomerado da Serra presents specific geomorphologic complications, because of the dense occupancy on the slopes, where three natural water springs which supply the main river of the city are found. Early inhabitants started to occupy the lower parts of the mountain and nowadays the hills are almost completely occupied, even on the upper parts and tops. A number of mudslides have occurred because of the incorrect use of the land practiced by local inhabitants and even by construction companies, which have been hired by the municipality for infrastructure interventions. It is possible to use such areas for housing, but it demands an integrated approach to the use of the land. Especially in this case, old residents have a deeper knowledge than regulators and planners. They have been there since the beginning, when there were almost no houses. They took part in the first changes of the environment and could actively observe and learn from it. For example, the construction in short steps usually helps the builder to observe the response of the environment, which is particularly adequate for the self-production in hilly topographies. The self-producer has time to make mistakes, learn and fix them, since each action takes years.

The family in building A, for example, has constructed their five-floor house over 40 years, and it has apparently never presented any structural defects. Building $C$ is an example of a very good use of hilly piece of land, as we can see in Figure 13. The lot is divided into small plateaus and small additions have been made step-by-step. This spatial strategy results in different housing units and entrances, which facilitates use by tenants, as can be observed in the next figure.

A remarkable aspect of new middle class residents of Aglomerado da Serra is the way of managing economic and material resources. Most families adopt more or less the same methods. First of all, they plan and decide themselves what should be done, which can be a small or big renovation, the addition of another room or a complete new house. The ideas are normally openly discussed among family members. Sometimes they draw them, sometimes they have everything only in mind and demonstrate it directly on the building site. After deciding what to build, it is time to find a trustworthy bricklayer able to do the work, who is normally recommended by friends or relatives. Decisions are strongly directed by emerging situations combined with economic restrictions. At this stage, we can observe one of the main differences between traditional planning and building processes and selfproduction processes. Self-production is rarely continued, but it is divided into cheap short steps, not planned as a whole integrated work. This means that the traditional and formal construction phases do not happen and that long pauses between phases can occur. For example, residents contact a bricklayer only to build some walls and, after some time, hire another one to fix the roof, or to build the foundations of a new addition and so on. A typical self-production process in Aglomerado da Serra starts with the visit of a bricklayer. He visits the building site to understand what the residents want. He has no formal plans, but talks to residents and makes 1:1 sketches on the floor with small shards of ceramic bricks. The worker estimates the quantity of building materials and gives a quote for how much his services will cost, when the work might begin and how long it will last. With this information, the family checks how much money they have been saving, how much is still needed and how many months are necessary to acquire the full amount. After a few months of saving, people buy construction items previously listed by the bricklayer, usually at the building material shop in the neighbourhood, which normally belongs to friends. People rarely pay cash, but finance the payment in monthly installments that last for more than one year in their credit card bill. The products stay at the shop because people have no space to store them. Only after purchasing all the items does the construction start. There is a time gap between the first visit of the bricklayer, when he first estimates the costs and time and the real beginning of the work. During this break, which can last months to years depending on how much money people still need to save and on private issues that interfere in decisions, prices are higher and most often the same bricklayer is not available anymore, having already been hired for another job. Time and money must be negotiated once again and the whole process happens again. After so much time, most workers do not give up the first job they have previously combined. They usually try to find time in their busy schedules, mostly working on weekends, in order to earn some extra money. The problem is that this practice rarely works out. What usually happens is the accumulation of delayed tasks, wasting of time and a deep dissatisfaction from users.

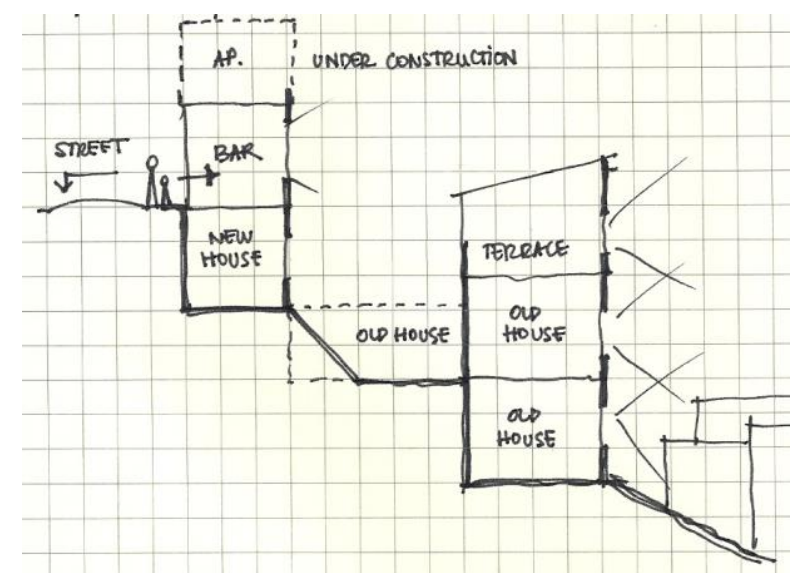

Figure 13. Case $C$, section plan of the complete lot. Source: drawing by the author, 2014. 
Neighbours and relatives often help workers. During the building process, new construction materials are always required, which are bought at the same shop, also financed with credit cards. At the end of the building process, the debts remain. This process, from the first quotation of the cost and materials needed, right up to the end of the construction process, repeats with each stage of construction, since they are not planned to happen at the same time or in sequence. This approach has nothing to do with conventional architectural practices, even technically or culturally. Although problematic, regarding the lifetime of building materials and a kind of technical harmony of unfinished parts of the building, these are the very common conditions of self-production.

Self-producers learn so much in their constructions and renovations that some of them have transformed the activity in a job. The owner of building $\mathrm{H}$, a formal lathe operator, started doing small renovations and additions for neighbours who have no time to do it themselves. One of his clients is the inhabitant of the house $G$ (Figure 14). She is currently renovating her old house, built in the late 70's, for the first time. He charges a cheap price and manages small building sites, designing, calculating building materials, hiring bricklayers, painters and helpers and also doing part of the work himself. He has been doing this for himself, since the construction of the family's house, from when they bought the lot to the renovations still in progress. It was not a choice he had, but a convenient solution to find a new career since his previous one is now obsolete: "my profession does not exist anymore. The Chinese arrived and took over the market. Then I had to do something else..." This informant is a very talented manual worker and is very aware of the future of Brazil's manual labour sector. Although he is very satisfied with the new business and enjoys working in a building site himself, he has faced complicated situations with construction workers. Bricklayers and their helpers, especially young ones, very rarely receive any kind of training in Brazil. There are almost no technical schools and people learn on the job, observing elder colleagues. This situation perpetuates mistakes and unreasonable attitudes on the building site. Technical problems are seen as normal and expected: "concrete slabs always infiltrate rainwater".

Besides, working as a construction worker is seen as undesirable. It is a stigmatized occupation-for the poor, the black and the uneducated, with precarious basic education and often problematic social and family backgrounds. The owner of building $\mathrm{H}$ fears the future of the cities. According to him, on one hand, as well as construction companies that build for wealthy clients and for the government, there are millions of self-producers with no access to technical assistance and that can only access autonomous construction workers, with absolutely no training or even a satisfactory basic education. This man has self-built his family home (Figure 15), where he has lived with his wife and three children since the early 80s. His workshop, in the back part of the lot, is abandoned while he starts a new professional life. He has also built a restaurant on the top of the original house, also as an alternative new job.

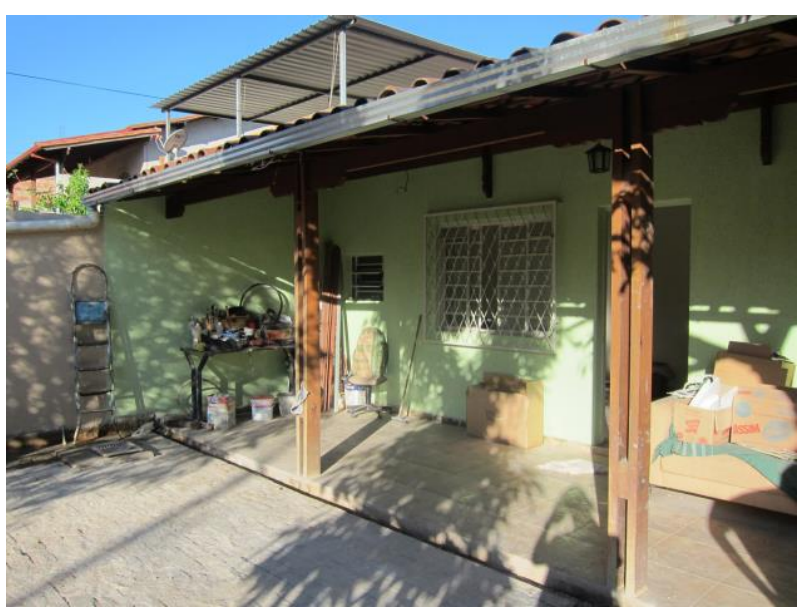

Figure 14. Case $\mathrm{G}$, renovations in course, managed by the friend and neighbour, informant of the case $\mathrm{H}$.

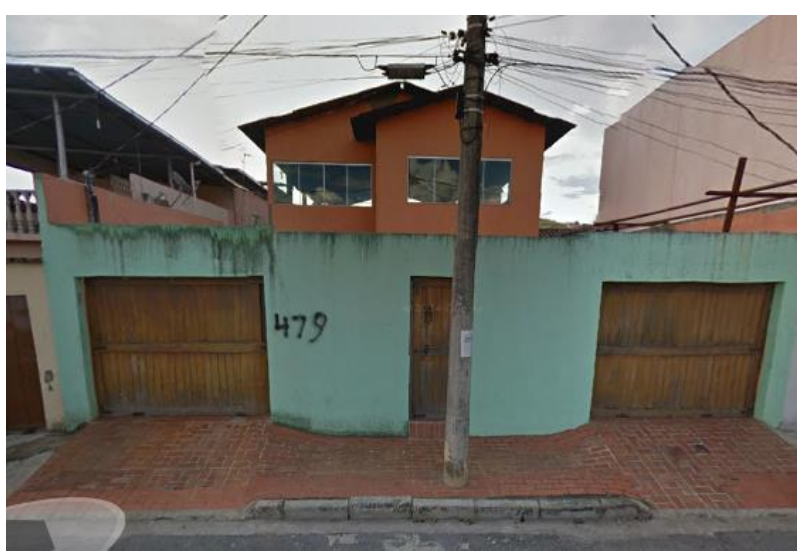

Figure 15. Case $\mathrm{H}$, upper floor can be used as a restaurant. Source: author's archive, 2013.

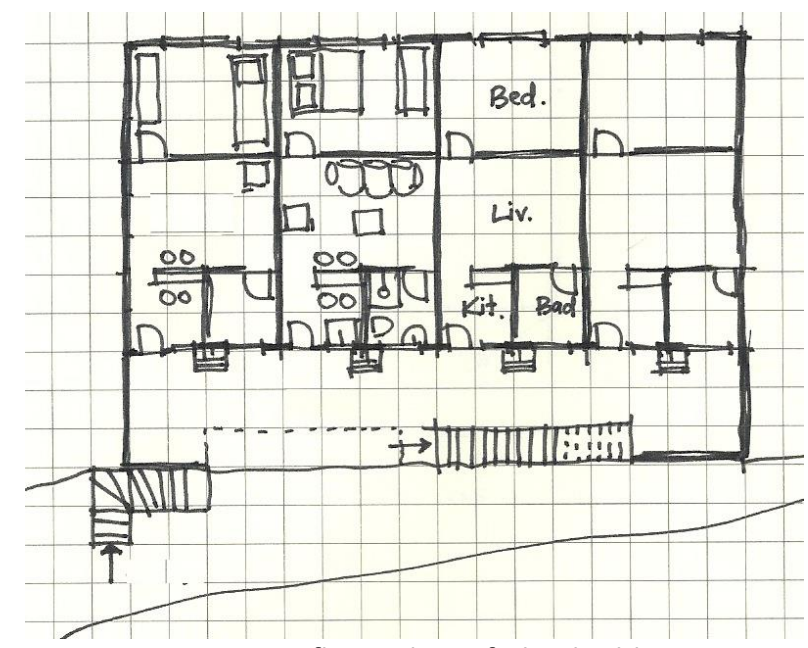

Figure 16. Case B, floor plan of the building. Source: drawing by the author, 2014. 


\subsubsection{Residences as an Exercise of Creativity}

As represented in Figure 16, the spatial concept of B is quite interesting. It is a kind of a terraced house, with four units per floor and three floors. All the units are exactly the same. They consist of a living room integrated with a small kitchen, a bathroom and a bedroom. The units are open to a common corridor in the front part of the building, where there are laundry spots and stairs to connect the floors. The building is extremely functional and has absolutely no architectural concept. Tidily inserted between many buildings, there is only one free facade, which is only seen from a narrow path that connects the building to the main street. Although it is well placed in the lot, which provides tolerable lighting and ventilation conditions to internal spaces, the quality of the construction is very unsatisfactory.

External walls present lots of assembly defects. They are not straight and have protuberances, wrong junctions and even small empty spaces between construction elements. This condition results in future technical problems, like the infiltration of rain water and the accumulation of dust and humidity. As the walls are not stuccoed and painted, they receive direct sun, wind and rain water, which reduces their lifespan. What usually happens is that some time after, layers of stucco and painting will be used to hide the defects, without really solving the problems (Figure 17). At that stage, the unprotected walls do not have the same technical conditions of before, but will still remain and will probably be used to support a second or even a third floor. The same happens with decks without water proofing and windows and beams installed without window ledges or external finishing.

The unfinished appearance can disturb architects, but it is not a problem for the owner or tenants. For residents, these buildings are a convenient solution for their needs and for the owner is more than a victory. It is a good business, which offers the young entrepreneur economic security now and in the future. In addition to economic power, he gains symbolic power, as he is recognized as a successful young businessman in the neighbourhood. The business reproduces some aspects of the production of residences in the formal city, but with one big difference. This is a self-production process, since the acquisition of the land to the renting business is completely informal. It means that he (and most self-producers in slums) has no registration or ownership documentation and, because of this, does not pay any taxes, either on the land's value or on the profit from the renting business. Since the land is not legal, theoretically nothing should have been built and consequently the apartments should not be rented. How to formalize construction on an informal property? Besides, construction workers were informally hired, with no working rights, but a simple contract that describes the duration and price of the work.

The young entrepreneur completed his secondary studies at night, since he had to work all day. Now he can afford a night course at a private faculty to become a civil engineer. Actually, he always wanted to complete his studies, but only decided to go for engineering after having started the construction process. It seems to be irony-the earnings coming from the informal construction pay for the engineering faculty.

As in the case of building $B$, building $E$ presents no aesthetic preoccupation and was "designed" to receive a right number of tenants, with tolerant ventilation, illumination and accessibility conditions. The owner had already self produced the house where he and his family currently live, somewhere in the neighbourhood. At that time, he had to hire some friends and eventually realized that he had to pay more per hour than he earned himself as a wall painter. This is why he decided to build himself the next time. Owning a private house is a dream for new middle class residents. Besides the symbolic value it carries, it grants the family the possibility of making savings, since they do not pay rent anymore. Savings offer new opportunities for a family - to buy goods, to invest in a new business, in a retirement plan and in the children's education. The owner decided to invest his savings in buying a half-lot.

Although half-lots are recognized by public notary's offices, the constructions there are normally informally built, again with no architects, engineers or formal plans. Despite the fact that they are located in the formal city, these enterprises do not follow urban regulations, are built without permission and are not allowed to be inhabited. The municipality regulators do not have bureaucratic conditions or human resources to inspect and control spontaneous construction in the city. Furthermore, the municipality in a way depends on self-production initiatives, since the demand for housing has never been solved.

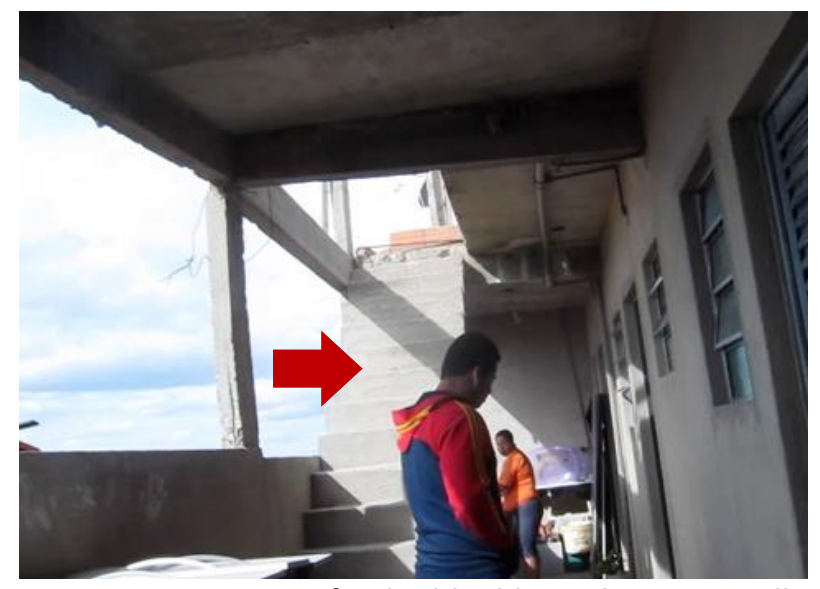

Figure 17. Case $B$, unfinished building. The arrow calls the attention to the stairs to the third floor, with no protection. Source: author's archive, 2013. 

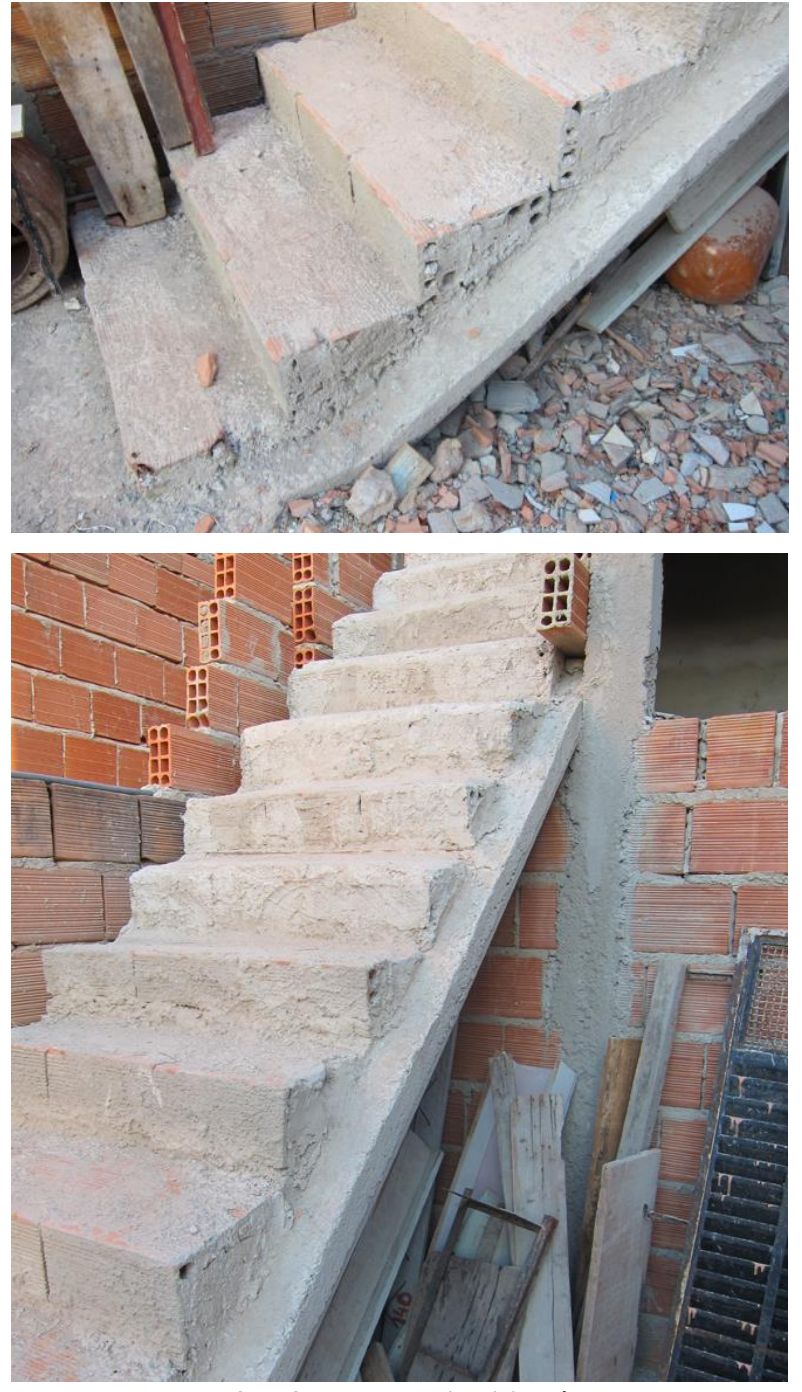

Figures $18 \mathrm{a}$ and $\mathbf{1 8 b}$. Case E, building's stairs. Source: author's archive, 2013.

The half-lot is $210 \mathrm{~m}^{2}, 7$ meters wide and 30 meters deep. The plan is to build two small blocks with four housing units separated by a common yard, and in the future, a small shop at the front (see Figure 10). Two housing units are already rented and the other two are about to be finished. As in B, external walls are not stuccoed or painted. The priority is to finish the housing units inside, to rent them out immediately and then to re-invest the money building the shop.

Besides the dwindling amount of free and green areas left, the spatial organization and distribution of the units on the lot is satisfactory. The construction does not present technical problems yet, although there are visible construction mistakes. For example, the technique used to build the stairs resulted in steps which are too high and not deep enough, as we can see in Figures $18 \mathrm{a}$ and $18 \mathrm{~b}$. Stairs are always a challenge for selfproducers and self-builders. Normally the space is limited and it is not so simple to fit adequate dimensions.

At a first sight, the dimensions and location of the windows seem to be unsatisfactory. Because they are in- stalled too high, so as to preserve the privacy of neighbours, residents can barely see outside. Furthermore, they are very small, approximately $1 \times 1 \mathrm{~m}$ and the beams are too deep, which is also an obstacle for natural lighting (Figure 19). The result is dark rooms. This defect could be easily solved with different aperture systems to separate ventilation from illumination, for example. The problem is that more sophisticated construction items are extremely expensive in Brazil, even for the upper middle class market. Higher models would assure better ventilation and illumination and shorter beams would also contribute.

A remarkable aspect of the construction is the distribution of the access to each housing unit. Each unit has one independent entrance. This solution offers more privacy for the residents, and the access also works as a backyard. At the same time it costs more, since each housing unit has its private access, sometimes only by stairs. In building B, accesses to each unit are used as common space, with laundry spots and some free space for outdoor activities. The result is a two-floor building with four housing units, each with two bedrooms, a living room, a kitchen and a bathroom. The adjacent residence, $F$, is another example of the same spatial organization strategy as was adopted in $\mathrm{E}$. In this case, the resident still lives in the lot, in the main house. There is a common yard in the middle, which is open to all housing units and provides ventilation and light for all of them (check Figure 10).

It is interesting to observe which aspects of selfproduction are direct references from the formal city and from regular constructions. In peripheral districts and in slums, repertories of form and architecture are few. Buildings do not to represent concepts, but attend to basic needs. Besides, construction materials do not vary much. People tend to repeat what they see on the streets, in their working environment and at friends and relatives' homes. The construction industry in Brazil is concentrated around the production of high-rise apartment buildings, obtaining the maximum profitable area and not focused on the optimal use of the space. In some sense urban regulations collaborate for this practice, since the required dimensions for ventilation, illumination and privacy are based on the minimum (Belo Horizonte, 2010). So, formal constructions are built according to the existing laws, but far from offering good space quality. Generally people think that "formal" and "regular" buildings are necessarily good. That is why the formal construction market influences self-production processes, as we can observe in cases $E$ and $F$ : "if the municipality approves a $1 \mathrm{~m} \times 1 \mathrm{~m}$ window, it might work out". Although habitual, the arbitrary reproduction of formal construction habits seems to also be motivated by the availability of construction items in the market. People do not have many choices and end up using what is easy and cheap to buy. Spatial decisions that do not directly depend on construction materials normally present a higher level of authenticity, which have brought about very creative spatial arrangements. 


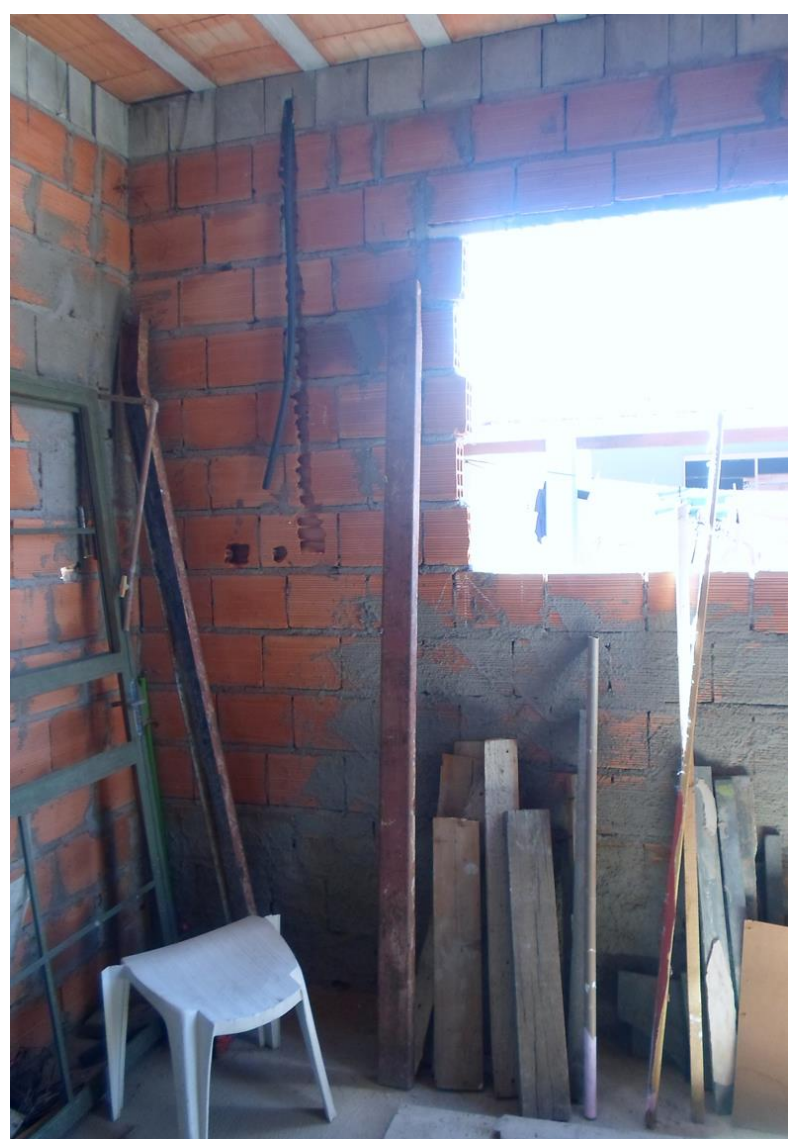

Figure 19. Case E, windows and high beams. Source: author's archive, 2013.

Inhabitants understand intimately their everyday demands and are perfectly able to imagine creative internal changes. House D, represented in Figures 20 and 21 , is an interesting example of how to manage the internal space of a residence where seven family members with different ages, schedules and demands live. In order to attend their wishes with limited costs and space, the matriarch of the family very well exercises the ability on choosing priorities and dealing with frustrations.

A couple, two daughters, two brothers and one niece live together in the three-room house. The couple, which owns the building, moved to Belo Horizonte about 25 years ago and soon after the wife invited her three brothers to join them (two of them still live there. One of them is the owner of the building B). It is very common that young people live with their parents for longer periods. This seems to have also economic justifications, since all family members collaborate on the household with economic and non-economic resources from a very young age. According to the owners, the house needs a new bedroom, a new laundry room and a bigger kitchen, since the old one has never been renovated. She also intends to renovate the existing garage and then to rent out it to contribute further to the family income. Parking spaces have also become a good business in the slums.

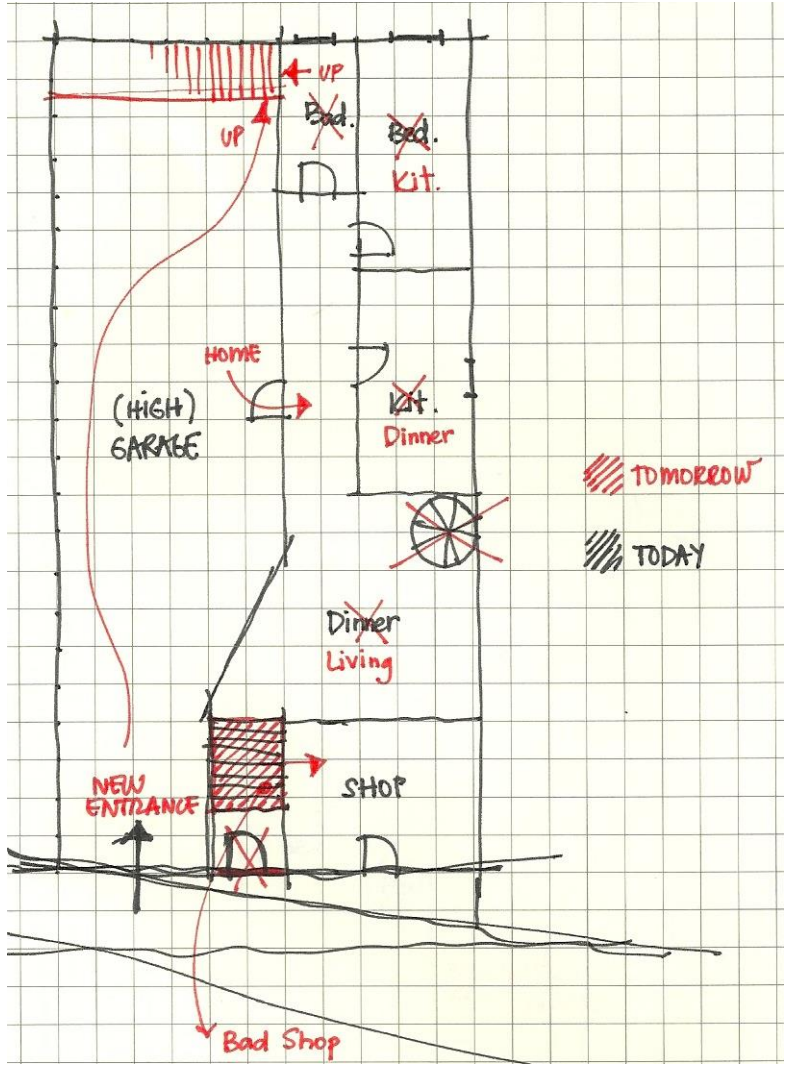

Figure 20. Case D, ground floor. Black represents the current situation and red the plans for the future. Source: drawing by the author, 2014.

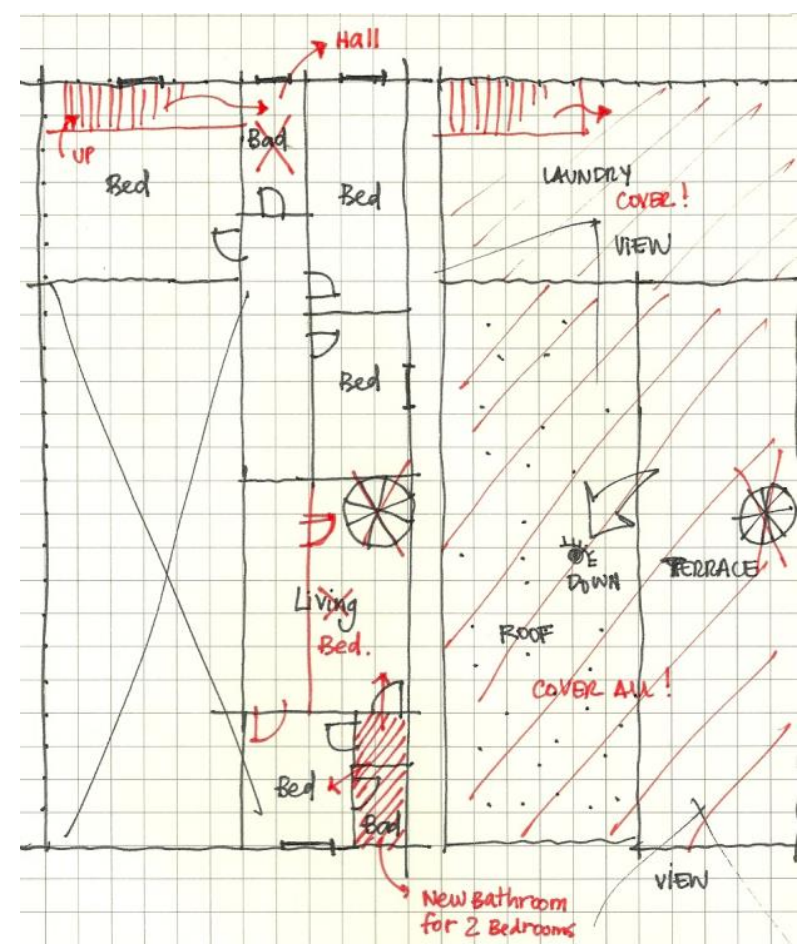

Figure 21. Case D, second and third floors. Black represents the current situation and red the plans for the future. Source: drawing by the author, 2014. 


\subsubsection{The residence as an Oasis in the Public Space}

The occupation of the neighbourhood and the construction of residences in both clusters occurred step by step. Residents did not arrive all at once, so twenty years ago neighbourhoods used to have lots of empty spaces. In formal subdivisions, these were private lots not yet occupied, but in the slums the differentiation between public and private is still not so evident. Empty places in slums were mostly free green areas. The environmental quality was not bad, although sanitary conditions were precarious.

The lack of collective life outside residences in peripheral neighbourhoods is reinforced by building types, with high front walls and grills. Also, public spaces are restricted to streets and sidewalks, which serve only as channels for of people going to work. In the area of the cluster in Aglomerado da Serra there is only one public space-Praça do Cardoso-and a few pieces of land which are not yet occupied because of geological risks. The nearest recreational space to São Joaquim, for example, is $5 \mathrm{~km}$ away, which can take about fifteen minutes by car but one hour by bus. On weekends the trip can take even longer, since the number of buses is reduced. There are no roads for bikes, sidewalks are narrow, less than 2 meters wide, and all types of vehicles are allowed to use the streets, regardless of their capacity. Moreover, sidewalks have trees planted on very small gardens, which offer unsatisfactory shadows and reduce even more their width. For wheel-chair users it is almost impossible to move around in many places in São Joaquim. In Aglomerado da Serra, the hilly topography is already a big difficulty. In both clusters, homes seem like an oasis in the harsh city. Inside them people surely feel more secure and comfortable. Many residences have gardens, with trees, vegetables and herbs. People sit on the shade and enjoy themselves. The concentration of investment in renovation and improvements to the recreational space of residences is also possibly motivated by the desire for an island of peace and security. Many houses have for example, a second kitchen in the backyard, where family members often meet for barbecues and private picnics, a kind of practice that in theory could take place in public parks. Although Aglomerado da Serra presents few planed public spaces, very narrow streets and almost no sidewalks, the streets present a more vivid atmosphere, always full of pedestrians, sellers, children and loud music.

The feeling of insecurity was much stronger during visits to São Joaquim than in Aglomerado da Serra. First of all, the journey to São Joaquim was much longer and took about 2 hours by bus from Belo Horizonte's city center. The trip is not direct-the bus takes highways and passes by areas where cases of violence have been known. When arriving in the neighbourhood, it was necessary to walk about 20 minutes from the bus stop to the cluster and as previously mentioned, the streets were always empty, and surrounded by high walls. On the other hand, Aglomerado da Serra is very well located and connected with three bus lines, which take about 20 minutes to get to the neighbourhood. There are many small shops on the way and many people on the streets, which somehow involves the want to create their own oasis of peace. Especially in the favela, there is a common preoccupation with children and teenagers. Many parents prefer to keep them inside the house as much as possible, to avoid contact with drug dealers, who run their businesses on the streets. At the same time, informants do not fear violence coming from the dealers, who actually are their neighbours, most of them since a very young age. The problems are involvement with illegal practices and the risk of conflicts between policemen and dealers, which can happen on the streets and contribute to an insecure atmosphere.

\section{Early Conclusions and Questions}

The hardest Brazilian problems are not individual, but collective: inequality, inflation, informality, lack of resources, violence, and lack of democracy- problems that contradictorily seem to belong more to the country than to each Brazilian individual (Neri, 2011). How can Brazilians rate their lives highly, as confirmed by researches of the Gallup World Poll Institute (2010, apud Neri, 2011) when it comes to future happiness and at the same time give a low grade for life in general? This conflict is also confirmed with families that took part in this research. All informants, without exception, agreed that life today is easier than life 20 years ago. Nowadays there are "jobs for everyone" and also better material conditions. At the same time, informants were not optimistic about politics, education, public security and health care. The assertion that "Brazilian problems are not private, but public", although applied to the economic context by Neri (2011), also fits here. The field work confirmed that in general, residences have really improved in the sense of internal comfort, sanitary conditions and available space, as well as the abundance of domestic goods. Although government initiatives like Bolsa Família and Construcard (a social welfare program that provides financial aid to poor families and a low interest loan for self-producers, respectively) took place in the last ten years and have positively influenced selfproduction processes, private companies are making an incredible profit through building due to insufficient government social housing enterprises and big infrastructure projects in the big cities. In any case, urban quality has not been taken as a priority. Governments have given priority to new construction and parking spaces, to the detriment of green areas and recuperation of old buildings. This behavior is blindly reproduced by self-producers in their homes. For example, although they have achieved creative solutions in the use of space, illumination and ventilation have minimal dimen- 
sions and every single meter is used, right up to the limits of each lot, so free or green areas are few.

So, after gaining an insight into how "battlers" reside, I ask: what do Brazilian "battlers" need? Based on this quick look through their homes, I would say they do not need much. Regarding their residences, the integration of three parallel actions seems to be an ideal to be pursuit: (a) training for manual workers and selfproducers and (b) alternative tools for understanding and planning space in collaboration with construction components (stairs, beams, slabs, windows etc). These are interesting research topics for architects, who would be, instead of space planners, a type of space facilitators. Finally, another idea would be to implement (c) low interest financing mechanisms for self-production processes, if they were flexible, non-bureaucratic and if they worked accordingly to the rhythm and the conditions of each family. Regarding neighbourhoods, in order to improve space quality, a deep change is necessary in mechanisms of urban planning, which are currently completely profit-making oriented and are not focused on optimal solutions for inhabitants. With the socioeconomic rise of the Brazilian new middle class, people seem to have a full right to their homes, given by an apparent economic stability and some freedom and autonomy on self-producing and self-building dwellings. At the same time planning tools and urban planning departments are completely focussed on private initiatives, which do not take quality of housing and of the urban environment as priorities. It is not by chance that selfproducers, which have so hardly resolved their own demand, are ignored by the state. People seem to have right to their private homes, though done by themselves, but still remain without right to the cities they inhabit. (Brenner, Marcuse, \& Mayer, 2012).

The recent economic growth of Brazil has contributed to improvements in the everyday life of families, in terms of basic resources for households. Unfortunately, the same level of improvements is not noticeable in the neighbourhood scale and even less in the city as a whole. Even though, in comparison with other emerging countries (Russia, India, China and South Africa), Brazil shows interesting distinctive aspects. On the one hand, social inequality is decreasing in Brazil and growing in other BRICS. Indeed, only in Brazil is the annual income of the $20 \%$ poorest growing more than the income of the $20 \%$ richest (OCDE, 2010), although Brazil's GDP grew by only $2.3 \%$ in 2013, much less than that of China, which grew $7.7 \%$. According to economists, the quality of Brazilian economic growth is better (or more trustable) in terms of environmental issues and working conditions. At the same time, Brazil has a weak educational public sector, confirmed by difficulties faced by most informants in their building sites; people do not save as much as in developed countries, as they face extremely high costs for the household, private schools and health care, as well as bureaucratic obstacles. While economists are optimistic, sociologists, architects and urban planners should be rather concerned.

\section{Acknowledgements}

I would like to thank the team of Cogitatio for this opportunity, my PhD mentor Professor Max Welch-Guerra and my Professor and friend Silke Kapp.

\section{Conflict of Interests}

The author declares no conflict of interests.

\section{References}

Belo Horizonte. (2010). Lei de Uso e Ocupação do Solo de Belo Horizonte, no 9.959, 20 July 2010.

Bourdieu, P. (2007). A distinção-Crítica social do julgamento(Brazilian edition). São Paulo: University of São Paulo Press.

Brenner, N., Marcuse, P., \& Mayer, M. (2012). Cities for People, Not For Profit. Critical Urban Theory and the Right to the City. New York: Routledge.

Descombe, M. (2003). The Good Research Guide for Small-Scale Social Research Projects (2nd ed.). Philadelphia: Open University Press.

Grupo de Pesquisa Morar de Outras Maneiras/Universidade Federal de Minas Gerais (MOM/UFMG). (2012). Nilberto, Luciana e Crianças-Research Report MTS (Moradia e Tecnologia Social). Belo Horizonte: UFMG

Kapp, S. (2005). Por Que Teoria Crítica da Arquitetura? Uma Explicação e uma Aporia. In M. L. Malard (Ed.), Cinco Textos sobre Arquitetura (1st ed., pp. 115-167). Belo Horizonte: Editora UFMG.

Konder, L. (1981. O Que É Dialética (28th ed.). São Paulo: Editora Brasiliense.

Leavy, P. (2011). Oral History-Understanding Qualitative Research. New York: Oxford University Press.

Neri, M. (2011). A Nova Classe Média-O Lado Brilhante da Base da Pirâmide (1st ed.). São Paulo: Editora Saraiva.

Nogueira, P. S., \& Kapp, S. (2010). Práticas de Arquitetura para Demandas Populares - A Experiência dos Arquitetos da Família (Master Thesis). Belo Horizonte: Minas Gerais Federal University.

OCDE. (2010). Latin American Economic Outlook 2011. Paris: OCDE Development Centre.

Souza, J. (2010a). Uma nova classe social. Le Monde Diplomatique Brasil, November, pp. 6-7.

Souza, J. (2010b). Os Batalhadores Brasileiros-Nova Classe Média ou Nova Classe Trabalhadora? (1st ed.). Belo Horizonte: Editora UFMG.

Weimer, G. (2005). Arquitetura Popular Brasileira. São Paulo: Martins Fontes. 


\section{About the Author}

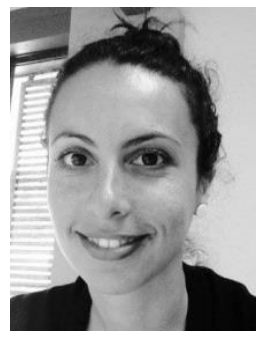

Priscilla Nogueira

Priscilla Nogueira is a Brazilian architect, interested in ordinary architecture, self-production processes and alternative design methods. From 2008 to 2011 she coordinated the project "Family Architects", providing technical assistance in low-cost building processes in Brazil. Since 2012 Priscilla Nogueira has been a PhD candidate at Bauhaus-Universität Weimar with the Doctoral Research "How do Brazilian "battlers' reside?". The work focuses on the production of space made by the so called "new Brazilian middle class", investigating the relations between social conditions of self-producers and technical and spatial conditions of produced spaces. 